https://doi.org/10.32689/2618-0065-2020-3(5)-9-21

Алексесва Катерина Андріївна, кандидат наук 3 державного управління, доцент кафедри виробничого та інвестиційного менеджменту, Національний університет біоресурсів і природокористування України, 03041, м. Київ, вул. Героїв Оборони, 11, навч. корпус № 10, каб. 413, Тел.: (044) 527-80-81, katerinaalex@ ukr.net, https://orcid.org/0000-0003-1129-0771

Грищенко Ірина Миколаївна, доктор наук з державного управління, професор кафедри публічного управління та менеджменту інноваційної діяльності, Національний університет біоресурсів і природокористування України, 03041, м. Київ, вул. Героїв Оборони, 11, навч. корпус № 10, каб. 209, Тел.: (067) 804-70-03, Gryschenkoiryna@ukr.net, https://orcid.org/0000$\underline{0002-8191-1177}$

\title{
УДОСКОНАЛЕННЯ ПРОЦЕСУ ІНФОРМАЦІЙНОЇ ВІДКРИТОСТІ ОРГАНІВ ПУБЛІЧНОЇ ВЛАДИ ШЛЯХОМ ПРАКТИЧНОЇ РЕАЛІЗАЦІЇ КОНЦЕПЦЇ̈ ЕЛЕКТРОННОГО УРЯДУВАННЯ
}

Анотація. Удосконалення діяльності системи органів публічної влади можливе тільки у разі забезпечення постійного зростання їх інформаційної відкритості. Сучасне розвинене суспільство не може існувати без забезпечення двостороннього зв'язку між органами публічної влади з, одного боку, та громадянами і бізнесом, з іншого боку. Власне, самі органи влади зацікавлені у наявності такого взаємозв'язку, оскільки, зростає довіра до них (органів публічної влади) та, відповідно, наявна підтримка певних, навіть непопулярних, рішень 3 боку населення країни. Відтак, зростання інформаційної відкритості органів публічної влади $\epsilon$ необхідною передумовою для розвитку сучасного публічного адміністрування загалом. На сьогодні підвищення інформаційної відкритості органів публічної влади варто забезпечувати шляхом впровадження системи електронного урядування.

Незважаючи на те, що дана проблема викликає зацікавленість у всьому світі, потреба у розробці конкретних підходів до ії вирішення в Україні не викликає сумнівів. Підвищення інформаційної відкритості органів публічної влади шляхом впровадження системи електронного урядування $\epsilon$ на теперішній час необхідним кроком, оскільки завдяки ньому можна покращити взаємозв'язок між органами влади та громадянами і бізнесом.

Метою статті є дослідження процесу інформаційної відкритості органів публічної влади шляхом практичної реалізації концепції електронного урядування. Для досягнення даної мети у статті виконуються такі завдання: по-перше, обгрунтовується потреба у підвищення інформаційної відкритості органів публічної влади загалом, по-друге, пропонується удосконалити 
інформаційну відкритість органів публічної влади шляхом практичного впровадження системи електронного урядування.

У статті наведено авторське бачення підходів до підвищення інформаційної відкритості органів публічної влади, а саме через впровадження системи електронного урядування. Зазначено, що підвищення інформаційної відкритості органів публічної влади повинно відбуватися на загальнодержавному, регіональному та місцевому рівнях.

Ключові слова: органи публічної влади, відкритість влади, інформаційна відкритість органів публічної влади, розвинене суспільство, система електронного урядування.

Kateryna A. Alekseieva, $\mathrm{PhD}$ in Public Administration, Associate Professor of the Production and Investment Management Department, National University of Life and Environmental Sciences of Ukraine, Ukraine, Kyiv, Heroiv Oborony 11, Str. (building No 10, room 413), Tel.:(044) 527-80-81, katerinaalex@ukr.net, https://orcid.org/0000-0003-1129-0771

Iryna Hryshchenko, Doctor of Science in Public Administration, Professor of the Department of Public Administration and Innovation Management, National University of Life and Environmental Sciences of Ukraine, Ukraine, Kyiv, Heroiv Oborony 11, Str. (building № 10, room 209), Tel.:(067) 804-70-03, Gryschenkoiryna@ukr.net, https://orcid.org/0000-0002-8191-1177

\section{IMPROVEMENT OF THE PROCESS OF INFORMATION OPENNESS OF PUBLIC AUTHORITIES BY THE PRACTICAL IMPLEMENTATION OF THE ELECTRONIC GOVERNMENT CONCEPT}

Abstract. Improvement of the activity of the system of public authorities is possible only if their information openness is constantly increased. A modern developed society cannot exist without a two-way connection between public authorities on the one hand, and citizens and business on the other. In fact, the authorities themselves are interested in having such a connection, as there is increasing confidence in them (public authorities) and, accordingly, there is support for certain, even unpopular decisions by the population of the country. Therefore, increasing the information openness of public authorities is a prerequisite for the development of modern public administration in general. Today public information authorities should be enhanced through the introduction of e-government.

Although this issue is of interest worldwide, the need to develop concrete approaches to its resolution in Ukraine is beyond doubt. Increasing the information transparency of public authorities through the introduction of e-government is now a necessary step because it can improve the relationship between government and citizens and business. 
The purpose of the article is to improve the process of information openness of public authorities through the practical implementation of the concept of egovernment. In order to achieve this goal, the following tasks are fulfilled in the article: firstly, the need to increase the information openness of public authorities in general is justified, and secondly, it is proposed to improve the information openness of public authorities through the practical implementation of the egovernment system.

The article presents the author's vision of the ways to increase the information transparency of public authorities, namely through the implementation of egovernment. It is stipulated in the article that such steps could significantly increase the relationship between public authorities and citizens, as well as public authorities and businesses. In addition, public information should be increased at the national, regional and local levels.

Keywords: public authorities, openness of government, information openness of public authorities, advanced society, e-government system.

Постановка проблеми в загальному вигляді. В Україні вже декілька років поспіль актуальним $є$ питання підвищення інформаційної відкритості органів публічної влади. Мова йде про двосторонній процес, тобто зростання інформаційної відкритості органів публічної влади повинно супроводжуватися зростанням попиту на послуги органів публічної влади 3 боку громадян та бізнесу. Конкретні кроки в цьому напрямку робляться вже не одне десятиліття, створені спеціальні інституції, покликані забезпечити відкритість діяльності органів влади, спрощення надання послуг та підвищення їх якості для задоволення потреб громадян. Серед таких інституцій Міністерство цифрової трансформації України, яке наразі здійснює велику просвітницьку роботу і щодо запровадження сервісу «Дія» 3 метою надання державних послуг онлайн, і в напрямі різних освітніх програм щодо: фінансової грамотності підприємців; цифрової освіти; роботи центрів надання адміністративних послуг; безпеки дітей в Інтернеті тощо. Створено Єдиний державний веб-портал відкритих даних.

Цього року Україна вперше стала учасником європейського дослідження щодо розвитку відкритих даних European Data Maturity Report. Дослідження триває протягом усього 2020 року, а його результати опублікують у грудні 2020. Open Data Maturity Report - щорічне дослідження, результати якого демонструють рівень розвитку відкритих даних у Європі. Експерти здійснюють оцінку за більш ніж 165 показниками, які об'єднують у чотири групи: політика відкритих даних, робота національного порталу, вплив відкритих даних на ключові сфери життя, якість даних, що публікуються. Open Data Maturity Report проводили вже п'ять разів за участі 32 країн.

Не зважаючи на величезний обсяг проробленої органами державної виконавчої влади та органами місцевого самоврядування роботи, питання підвищення інформаційної відкритості органів публічної влади шляхом 
практичного впровадження електронного урядування, зокрема через удосконалення систем відносин «держава-громадяни», «громадяни-держава», «бізнес-держава», «держава-бізнес» на загальнодержавному, регіональному та місцевому рівнях залишається актуальним.

Аналіз останніх досліджень і публікацій. Різноманітні питання забезпечення інформаційної відкритості органів публічної влади перебувають у полі зору й досліджуються науковцями та практиками, серед яких: Е. Афоніна, Т. Андрійчук, Л. Горбата, О. Карпенко, О. Крет, М. Мельниченко, О. Радкевич, Є. Тихомирова, Б. Шевчук, І. Ткач, О. Твердохліб, С. Чукут та ін.

Серед зарубіжних дослідників питаннями інформаційної відкритості займалися Р. Гібсон, О. Тофлер, Й. Масуда та ін.

Дана праця безпосередньо пов'язана із науковими дослідженнями кафедри публічного управління та менеджменту інноваційної діяльності Національного університету біоресурсів і природокористування України, які здійснюються у межах науково-дослідної теми "Теоретичні засади i механізми реалізації інноваційних процесів у публічному управлінні” (ДР №118U100146).

Метою статті $є$ удосконалення інформаційної відкритості органів публічної влади шляхом практичної реалізації концепції електронного урядування.

Для досягнення мети визначено такі завдання:

обгрунтувати потребу у підвищенні інформаційної відкритості органів публічної влади;

удосконалити інформаційну відкритість органів публічної влади шляхом практичного впровадження системи електронного урядування.

Виклад основного матеріалу. Наразі теорія та практика державного управління підтверджує той факт, що розвинене суспільство неможливо побудувати, якщо перманентно не працювати над підвищенням інформаційної відкритості органів публічної влади. У XXI ст. суспільство щодня зіштовхується 3 усе новими і новими викликами, спричиненими власне розвитком цивілізації. Недарма ще в 2011 р. Організацією Об'єднаних Націй наявність вільного доступу до Інтернету було визнано одним 3 фундаментальних прав людини [1], а Конгрес Ради Свропи неодноразово закликав публічні органи влади через відкриті дані надавати громадянам доступ до інформації, що є важливою передумовою їх впливу на роботу обраних ними представників влади. Саме тому ключовими елементами демократичного врядування зараз стали відкритість, прозорість, а також підзвітність.

У сучасному суспільстві можна виокремити такі пріоритетні напрями забезпечення інформаційної відкритості: доступ до публічної інформації; розвиток політики е-урядування та відкритих даних [2]. 
Зважаючи на це, більш ніж дев'яносто країн світу за останні два десятиліття прийняли низку законів про забезпечення відкритості органів публічної влади, оскільки у них є абсолютне розуміння того, що право на доступ до інформації є невід'ємним правом людини і громадянина.

Серед таких держав особливої уваги заслуговує законодавство Сполучених Штатів Америки, які стали однією з перших країн, що закріпила обов'язок органів публічної влади інформувати громадськість про організацію своєї повсякденної діяльності відповідно до Акта про свободу інформації 1967 р. [3]. У 1996 році він був доповнений Актом електронної свободи інформації, що гарантує доступ громадськості до публічної інформації за допомогою електронних засобів.

Варто зазначити, що для забезпечення доступу до публічної інформації в Сполучених Штатах Америки створено Службу визначення місцезнаходження публічної інформації. Для заохочення приватного сектору до комерційного використання інформації, що знаходиться у володінні органів влади, прийнято Закон «Про скорочення паперової роботи».

Важливим пунктом реалізації відкритого урядування у США стало підписання «Меморандуму щодо прозорості і відкритого урядування» [4], зокрема, відкриття публічних даних. Портал містить інструменти для інтерактивної взаємодії, що дозволяють відвідувачам ставити запитання онлайн, повідомляти про проблеми із користуванням порталом, надсилати свої коментарі та пропозиції, запити на набори даних, спілкуватись на тематичному форумі тощо.

У Великобританії, яка вже чотири роки поспіль очолює рейтинг відкритих даних серед країн-лідерів у 2000 р. прийнято Закон «Про свободу інформації», яким передбачено: визначити вимоги до публікації: вид та спосіб оприлюднення, платне чи безоплатне ії отримання; приймати чи переглядати вимоги до публікацій враховуючи суспільний інтерес, публікуючи мотиви прийнятих рішень; застосовувати тест «заподіяної шкоди» при розголошенні інформації з обмеженим доступом, якщо іiі розкриття може заподіяти шкоду певним інтересам (у випадках питань охорони здоров'я та безпеки, доступ до неї обмежено, якщо ії розголошення може зашкодити фізичному або психічному стану особи) [3, с. 52].

Поряд 3 тим, органи публічної влади виконують два основні завдання: перше пов'язане з реалізацією права суспільства на отримання достовірної інформації щодо діяльності влади, друге - із побудовою іміджу органів публічної влади та формуванням позитивної думки щодо їх роботи. Для цього створено систему підрозділів, що виконують функції управління новинами. Так, для зв'язків із громадськістю у Великобританії створено Комітет стратегічних комунікацій, до складу якого входять директори 12 регіональних відділів інформації, особисті секретарі кожного міністра та шість представників різних партій. Комітет стратегічних комунікацій вирішує, яку саме інформацію уряд повинен надати населенню. Щоранку 
через прес-секретаря прем'єр-міністра члени цього Комітету отримують інформацію 3 Комітету моніторингу 3МI, проводять аналіз громадських думок про діяльність уряду та вирішують, яким чином на це реагувати.

Отже, Великобританія, так як і США, дбає про формування хорошого іміджу органів публічної влади серед населення. Така позиція підкріплюється й щотижневими соціологічними опитуваннями, які проводяться за допомогою фокус-груп, результати яких щопонеділка обговорюються в Комітеті стратегічних комунікацій. Із врахуванням цих результатів здійснюється пошук «фактів-убивць» (killer-facts), оприлюднення яких покращило б уявлення про роботу уряду. Створено спеціалізований дослідницький підрозділ для пошукової діяльності.

Доцільно звернути увагу на те, що Комітет стратегічних комунікацій виконує важливу в контексті окресленої проблеми функцію: жодна інформація, що стосується органів публічної влади, не може бути опублікована без узгодження часу публікації з Комітетом. Такий процес здійснюється за допомогою спеціального відділу і спеціального комп'ютера, який називається «Порядок денний» (Agenda) та встановлює графік публікації урядових повідомлень. Всі департаменти повинні домовлятися 3 відділом про час оприлюднення своєї інформації, щоб важливі повідомлення не перекривалися менш важливими.

Варто зазначити, що елементом системи управління новинами $\epsilon$ «комп’ютер швидкого реагування», на якому створена база даних, що постійно поповнюється. Вона містить висловлювання різної тематики, що стосуються політики, державних та політичних діячів, журналістів газет i телебачення. У разі потреби можна знайти «компромат» на опонента влади (його висловлювання 3 певної тематики) та аргументи на захист певної позиції владних структур чи державних діячів. Цей комп'ютер пов’язаний із урядовими департаментами в регіонах і Центральним бюро інформації та його регіональними відділами. Особливе місце в структурі Комітету стратегічних комунікацій посідає відділ спічрайтерів (speechwriter), які готують промови для міністрів або пишуть статті, що друкуються за підписом прем’єр-міністра або міністра, а також відділ спін докторів (spin «вертіння», «кружляння», doctor - «лікування»), які надають урядову інформацію в ЗМІ під найбільш вигідним кутом зору. Оскільки виникають ситуації, коли в засоби масової інформації потрапляє інформація, що може бути небезпечною для національних інтересів, уряд наділений повноваженнями (Директива «Д») заборонити газетам їі друкувати [5].

Проте, така активна робота щодо відкритості діяльності органів публічної влади спостерігається далеко не у всіх країнах. Не винятком є i Україна, де недосконалі механізми забезпечення відкритості діяльності органів публічної влади та невідпрацьована інформація стає причиною суспільних збурень і формує негативний імідж органів влади.

Для вирішення цієї проблеми в Україні стрімкими темпами формують 
законодавчу базу, створюють нові інституції, вводять різні он-лайн платформи. Так, Міністерство цифрової трансформації на початку 2020 р. провело презентацію мобільного додатку “Дія" та національної онлайнплатформи “Дія. Цифрова грамотність”. Це мобільний застосунок, покликаний зберігати всі необхідні документи в електронному вигляді. Запущено електронні посвідчення водія та свідоцтво про реєстрацію транспортного засобу. Перша національна онлайн-платформа “Дія. Цифрова грамотність”, покликана сприяти громадянам в освоєнні базових цифрових навичок. Реалізація проекту дасть можливість створити електронні публічні сервіси, що зменшать взаємодію з чиновниками. Передбачається робота над підвищенням рівня цифрової грамотності.

Уряд України визначив пріоритетом - стати світовим лідером за кількістю електронних адміністративних послуг. Передбачається, що кількість чиновників, що приймають рішення, буде зведено до мінімуму. Створюється єдиний портал, де буде зібрано всі державні послуги. Інформація з усіх реєстрів для кожного громадянина зосередяться в єдиному аккаунті. Людина отримає можливість доступу до всіх даних, якими володіє про неї держава. Важливо, що користувач буде отримувати повідомлення про спробу отримати доступ до його персональних даних. Пропонується окрім Міністерства цифрової трансформації, створити відповідні посади у кожному органі публічної влади [2, с. 26].

Отже, активізація дій уряду України та органів публічної влади у напрямі забезпечення відкритості діяльності вказує на бажання владних суб'єктів поділитися владою з об'єктами влади, причому об'єкти влади можуть на певний час перетворитися на суб'єктів влади, набувши певних владних повноважень [6].

Відкритість влади не $\epsilon$ ціллю, але певним інструментом для забезпечення зворотного зв'язку та підтримки від громадян. По суті, в умовах розвиненого суспільства влада сама зацікавлена у наявності такого зворотного зв'язку у формі довіри та підтримки громадянами обраного курсу, а також певних, навіть непопулярних рішень.

На рис. 1 схематично зображено суспільні наслідки відкритості діяльності органів публічної влади, що виникають через налагодження системного зворотного зв'язку. Такий зворотний зв'язок, по-перше, сприяє прямому діалогу між органами публічної влади та суспільством, а значить діяльність органів влади більш спрямована на забезпечення потреб громадян. Громадяни, в свою чергу, отримавши задоволення своїх потреб, висловлюють підтримку щодо діяльності органів публічної влади. По-друге, суспільство $є$ постійно інформованим з приводу потенційно можливих змін. Постійний моніторинг суспільної думки дозволяє представникам влади бути в курсі наявних на певний період часу настроїв та, приймаючи певні рішення, зважати на них. 


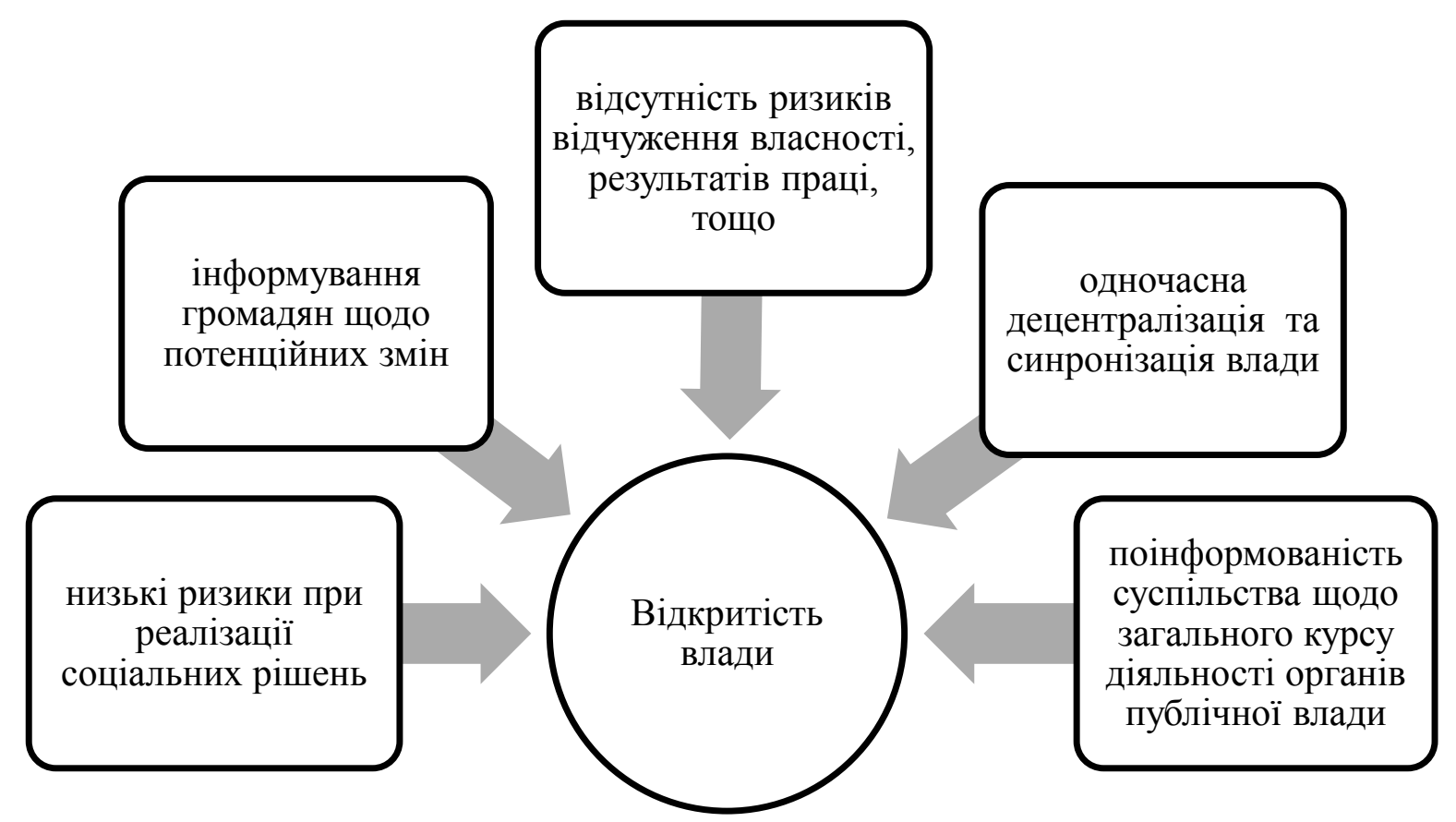

Рис 1. Суспільні наслідки забезпечення відкритості влади Джерело: Розроблено автором на основі [3]

По-третє, громадяни володіють економічною стабільністю та відокремленістю, зокрема впевненістю у неможливості відчуження у них власності або результатів їх діяльності у будь-якому вигляді, чи то продукції, чи то доходів від різноманітних видів господарської діяльності. По-четверте, важливою умовою забезпечення відкритості влади $\epsilon$ забезпечення децентралізації влади разом 3 синхронною роботою всіх іiі елементів. Це означає, що певна автономність при прийнятті рішень повинна супроводжуватися дотриманням єдиних стандартів, правил, процедур та рухом до єдиної загальної мети. Діяльність різних владних структур не повинна суперечити та дублювати одна одну. По-п'яте, суспільство повинно бути поінформованим щодо загального стратегічного курсу діяльності органів публічної влади, що формує певну колективну свідомість та громадянську культуру.

Наступним напрямом забезпечення інформаційної відкритості, про які вже згадувалося вище, є розвиток політики е-урядування.

Схвалена розпорядженням Кабінету Міністрів України від 20.09.2017 № 649-р Концепція е-урядування, рамково окреслює розвиток діджиталізованої (цифрової, електронної) системи адміністрування на всіх рівнях публічної влади: державному, регіональному та місцевому.

Метою впровадження електронного урядування в Україні є досягнення європейських стандартів якості електронних адміністративних послуг, відкритості та прозорості влади для громадян, представників бізнесу та громадських організацій.

Електронне урядування виконує такі основні функції: 
- підвищення якості та доступності послуг для громадян, спрощення процедур та скорочення адміністративних витрат;

- підвищення якості адміністративних та управлінських процесів, забезпечення контролю за результативністю діяльності органів виконавчої влади з одночасним забезпеченням належного рівня інформаційної безпеки;

- забезпечення відкритості інформації про діяльність органів публічної влади, розширення доступу до неї та надання можливості безпосередньої участі громадян та інститутів громадянського суспільства у процесах підготовки та експертизи проектів рішень, які приймаються на всіх рівнях державного управління;

- видача дозволів (на зайняття окремими видами підприємницької діяльності; на проведення мітингів, демонстрацій; на розміщення реклами та ін.), у тому числі акредитація, атестація, сертифікація;

- реєстрація (прав власності, актів громадянського стану, суб'єктів підприємницької діяльності, об'єднань громадян тощо);

- легалізація документів (консульська легалізація), нострифікація та верифікація;

- визнання певного статусу, прав особи (призначення пенсій, субсидій) [2, c. 30-31].

Уже можна спостерігати низку позитивних кроків щодо практичного втілення концепції електронного уряду. Зокрема, уже запроваджено ряд пілотних проектів із забезпечення електронними послугами громадян. До таких послуг віднесено електронні ідентифікації, інтерфейси, створення системи електронних кабінетів, надання он-лайн консультацій та ін. На жаль, поки що попит на електронні послуги з боку громадськості залишається низьким, в тому числі внаслідок низької поінформованості населення, відсутності довіри до влади, а також недостатнього доступу до Інтернету в селах та малих містах України. «Цифрова грамотність» залишається викликом для людей у сільських місцевостях, де навіть базові комп'ютерні знання викладаються не в усіх школах через неякісне матеріально-технічне забезпечення та відсутність фахівців, готових працювати за межами великих міст. Також підключення до мережі Інтернет є не скрізь, та використовується не всіма громадянами.

Поряд 3 тим, $\epsilon$ конкретні досягнення щодо електронного урядування громадських організацій в Україні, які впроваджують електронні інтерфейси для перманентного зв'язку зі своїми користувачами. Для роботи системи електронного урядування громадських організацій потрібно удосконалити роботу державних установ у напрямку збільшення рівня їх діджиталізації, оскільки поки що там наявні суттєві недоліки.

Зокрема для прискорення процесів діджиталізації діяльності органів публічної влади 3 метою підвищення їх інформаційної відкритості варто застосовувати різноманітні моделі державно-приватного партнерства iз 
залученням приватного капіталу та застосуванням аутсорсингової форми для практичної реалізації концепції електронного урядування. У теперішніх умовах органи публічної влади не можуть виключно власними зусиллями переорієнтовувати всю діючу модель надання послуг та проводити діджиталізацію власними силами, оскільки часто діють в умовах обмежених бюджетів. Залучення приватних капіталів дозволить збільшити інформаційну відкритість органів публічної влади уже в найкоротші терміни.

На рис. 2 відображено «Дорожню карту» розвитку відкритих даних в Україні, що містить 5 основних напрямків реалізації. Такими напрямками $є$ підвищення доступності та якості відкритих даних, розвиток спроможності органів влади щодо публікації відкритих даних, посилення ролі відкритих даних у реалізації державної політики, нормативно-правове забезпечення процесу розвитку відкритості даних та розвиток попиту та спроможності цільових аудиторій щодо використання даних.

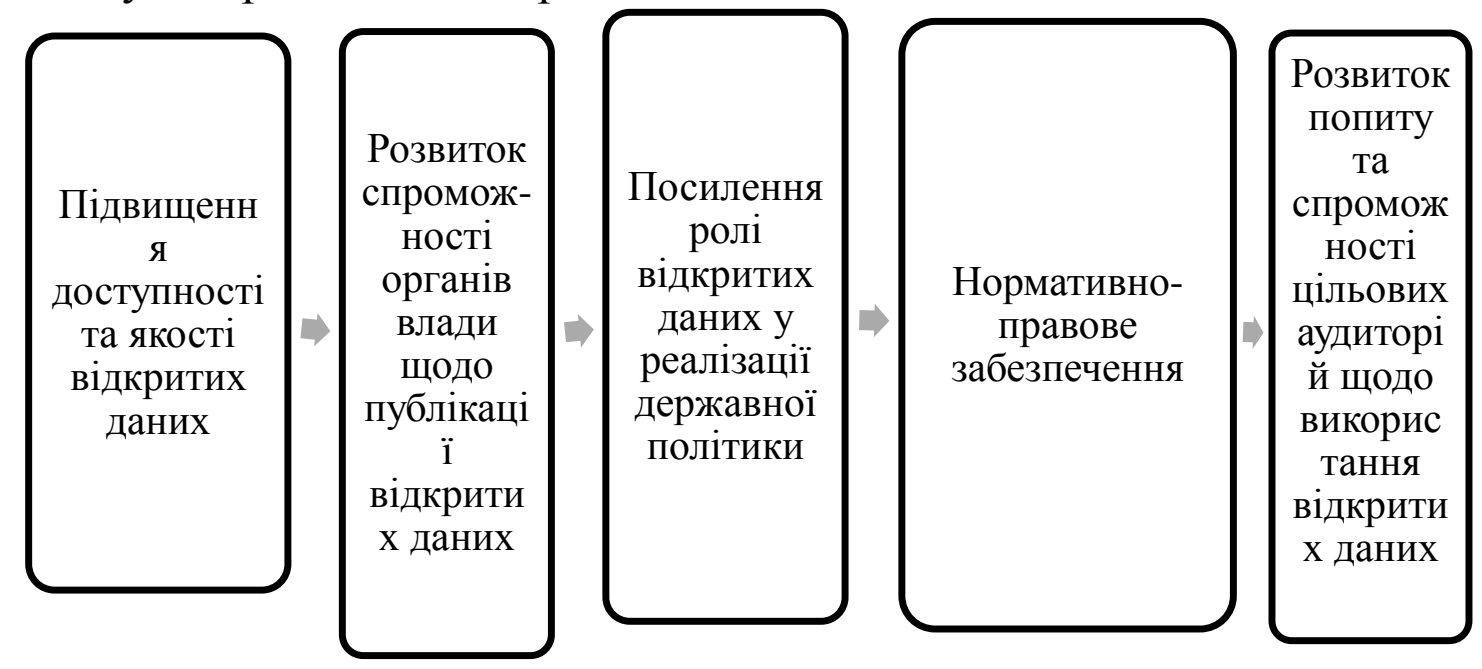

Рис 2. «Дорожня карта» розвитку відкритих даних в Україні Джерело: розроблено автором

Варто визнати той факт, що органи публічної влади не завжди $є$ готовими та охочими до збільшення рівня своєї інформаційної відкритості. Електронні платформи, які зараз активно розробляються, для розвитку ідей та впровадження проектів із залученням приватного капіталу на базі доступних даних частково можуть нівелювати потребу у деяких видах діяльності органів публічної влади, знижуючи ступінь їх бюрократизації. Це, безумовно, може викликати опір чиновників, оскільки у подальшому здатне призвести до усунення потреби у певних посадах в органах публічної влади або навіть у необхідності оптимізації роботи певних відділів шляхом їх об'єднання або закриття. Однак, паралельно це дозволить здійснити економію бюджетних коштів, а штати в органах публічної влади є часто надміру «роздутими» та вимагають оптимізації. Зрозуміло, що із загально суспільних позицій скорочення штатів та економія бюджетів стане явищем позитивним. 
На сьогодні в Україні важливим кроком у напрямку збільшення інформаційної відкритості органів публічної влади повинно стати формування попиту на інформаційні послуги цих органів з боку звичайних людей та бізнесу. Суспільна свідомість українців внаслідок попереднього авторитарного розвитку продовжує змушувати людей «самоусуватися» від прямого контакту з представниками органів влади. Громадяни України доволі часто прагнуть вирішити свої проблеми самостійно, іноді навіть приховавши свою діяльність та свої мотиви. Нерозуміння людьми доцільності державних заходів $є$ гальмівним фактором при їх здійсненні, адже саме громадяни України створюють попит на інформаційні послуги органів публічної влади. Тому поінформованість громадян стає ключовим чинником збільшення такого попиту, обумовлює та стимулює розвиток власне системи органів публічного управління.

Що стосується попиту на інформаційні послуги органів публічної влади з боку бізнесу, то такий попит може стати тим економічним чинником, який простимулює якісні зміни всередині системи, зокрема формування культури відкритих даних. Органи публічної влади будуть просто змушені відповідати на зростаючий попит 3 боку приватних осіб, які володіють певними фінансовими ресурсами та є готовими реалізовувати свої проекти. Виникне потреба у створенні нових та розвитку існуючих електронних площадок, тобто попит на такі площадки формуватиме їх пропозицію.

3 практичної точки зору, реалізація концепції електронного урядування передбачає здійснення кількох важливих кроків, які будуть спрямовані на удосконалення системи відносин «держава-громадяни», «громадянидержава», «бізнес-держава», «держава-бізнес» на загальнодержавному, регіональному та муніципальному рівнях. По суті, громадяни отримують доступ до публічної інформації та можливість здійснювати адміністративні послуги, використовуючи доступ до всесвітньої мережі. Завдяки роботі інтерфейсів, електронних кабінетів, систем опитування та інших інструментів залучення громадян до системи електронного урядування громадяни зможуть напряму брати участь у творенні та реалізації державної політики, висловлюючи свою думку та впливаючи на рішення органів публічної влади. Бізнес отримує можливість без організацій-посередників співпрацювати з органами публічної влади завдяки спрощеному доступу до інформації. Це, звичайно, у подальшому перетворюється на позитивний чинник економічного розвитку, оскільки «бюрократична тяганина» $є$ одним із вагомих стримуючих факторів ведення бізнесу в Україні. Органи публічної влади у таких умовах підвищують ступінь свого оперативного реагування на ситуацію, ефективність своєї діяльності, якість надання послуг, та володіють інформацією щодо пануючої громадської думки.

Висновки та перспективи подальших досліджень. У статті наведено авторське бачення процесу удосконалення інформаційної відкритості органів публічної влади шляхом практичної реалізації концепції електронного 
урядування. Зокрема, обгрунтовано потребу у підвищенні інформаційної відкритості органів публічної влади. Розвинене суспільство не може існувати без відкритого доступу до інформації щодо діяльності органів публічної влади. Повинен існувати двосторонній взаємозв'язок між органами публічної влади, з одного боку, та громадянами і бізнесом, з іншого. Завдяки цьому можна забезпечити ряд позитивних зрушень у системі державного управління певної країни, які у перспективі ведуть до соціальної згоди та підвищення довіри до влади.

Запропоновано удосконалити інформаційну відкритість органів публічної влади шляхом практичного впровадження системи електронного урядування. Такий підхід $\epsilon$ новим пріоритетним напрямом у політиці збільшення доступу до інформації щодо діяльності органів влади. Здійснити практичне впровадження системи електронного урядування можна шляхом розвитку процесів діджиталізації на всіх рівнях державного управління (загальнодержавному, регіональному, місцевому). Конкретні кроки у цьому напрямку уже зроблені на сьогодні, однак все ще наявні виклики, зокрема потрібно стимулювати не тільки пропозицію інформаційних послуг з боку держави, але стимулювати попит на такі послуги з боку громадян та бізнесу.

\section{Література:}

1. ООН визнала доступ до Інтернету невід’ємним правом людини. / Уніан. 2011. URL: $\quad$ https://www.unian.ua/science/504107-oon-viznala-dostup-do-internetu-nevidemnimpravom-lyudini.html (дата звернення 23.03.2020).

2. Грищенко I.M., Горбата Л. П. Пріоритетні напрями та шляхи забезпечення інформаційної відкритості в органах публічної влади. Public and municipal administration: theory, methodology, practice: Collective monograph. Riga: Izdevnieciba "Baltija Publishing", 2020. P.20-40. DOI: https://doi.org/10.30525/978-9934-588-46-4.02

3. Gorbata L. P. Foreign experience of information openness in the activities of public authorities, Austrian Journal of Humanities and Social Sciences, 2020, № 1-2. P. 51-57. DOI: https://doi.org/10.29013/AJH-20-1/2-51-57

4. Guidelines on Open Government Data for Citizen Engagement. Department of Economic and Social Affairs. Division for Public Administration and Development Management. United Nations. New York., 2013 URL: http://workspace.unpan.org/sites/Internet/Documents/Guidenlines\%20on\%200GDCE\%20May1 7\%202013.pdf (дата звернення: 03.07.2020).

5. Тихомирова Є. Б. Державне управління новинами як фактор інформаційної безпеки. URL: http://academy.gov.ua/ej/ej3/txts/GALUZEVE/03-TIXOMIROVA.pdf (дата звернення: 03.03.2020).

6. Що значить відкритість влади? 2009. URL: https://konstantinus.com/articles/shhoznachit-vidkritist-vladi/ (дата звернення 27.03.2020).

\section{References}

1. OON vyznala dostup do Internetu nevidiemnym pravom liudyny. 2011. Retrieved from: https://www.unian.ua/science/504107-oon-viznala-dostup-do-internetu-nevidemnim-pravomlyudini.html [in Ukrainian]. 
2. Public and municipal administration: theory, methodology, practice : Collective monograph. Riga : Izdevnieciba "Baltija Publishing", 2020. 324 p. Gorbata L., Hryshchenko I. Priority areas and ways to ensure information openness in public authorities. P. 20-40. DOI: https://doi.org/10.30525/978-9934-588-46-4.02.

3. Gorbata L. P. Foreign experience of information openness in the activities of public authorities, Austrian Journal of Humanities and Social Sciences, 2020, № 1-2. P. 51-57. DOI: https://doi.org/10.29013/AJH-20-1/2-51-57

4. Guidelines on Open Government Data for Citizen Engagement. Department of Economic and Social Affairs. Division for Public Administration and Development Management. United Nations. New York., 2013 URL: http://workspace.unpan.org/sites/Internet/Documents/Guidenlines\%20on\%20OGDCE\%20May1 7\%202013.pdf

5. Tixomirova E. Public news management as a factor of information security. URL : http://academy.gov.ua/ej/ej3/txts/GALUZEVE/03-TIXOMIROVA.pdf [in Ukrainian].

6. Shcho znachyt vidkrytist vlady? 2009. Retrieved from: https://konstantinus.com/articles/shho-znachit-vidkritist-vladi/ [in Ukrainian]. 